\title{
感光性樹脂の基礎
}

山岡 亞夫*

\section{Introduction to Photosensitive Polymers}

Tsuguo YAMAOKA*

*千葉大学工学部情報画像工学科（ \% 263-8522 千葉県千葉市稲毛区弥生町1-33）

*Department of Information and Imaging Science, Chiba University (1-33 Yayoi-cho, Inage-ku, Chiba-shi, Chiba 263-8522)

\section{1.はじめに}

感光性樹脂は光を照射することにより内在する感光物質 や感光基が逐次的または連鎖的な反応を起こし，本来有す る性質が顕著に変化する高分子材料の総称である。光照射 で変化する性質は表 1 のように様々であり，これらの物性 の変化を利用して広い分野で利用される。

\section{2. フォトレジストと感光性樹脂}

フォトレジストとはエッチング，めっき，はんだめっき などの工程でこれらの処理から表面を保護する機能をもつ 感光性樹脂の一種である。また，オフセットやスクリーン 印刷の製版には古くから使用されていた。LSIなど超微細 加工に㧍けるキーテクノロジとしての役割も果たしてい る。それぞれ使用される目的により，必要なスペックは著 しく異なる。

\section{1 エッチング用液体レジスト}

エッチング用レジストの組成は大きく分類すると光架橋 タイプと光重合タイプに大きく分類され，前者は薄膜で高 解像度を要するもの, 後者は厚膜の状態で使用されること が多い。

フォトレジストの電子工業分野での最も基本的な応用は 金属のエッチングで, 初期にはトランジスタやカラーテレ ビCRTのシャドーマスク等の製造から使用され始めた。

表1. 光照射による高分子の構造変化とそれに伴う材料物性の変化

\begin{tabular}{ll}
\hline 化学構造変化 & 特性変化 \\
\hline 光架橋 & 溶解性 \\
光分解 & 接着性 \\
光解重合 & 粘着性 \\
官能基の光変化 & 表面のぬれ性 \\
モノマーの光重合 & 屈折率 \\
& 液体 $\rightarrow$ 固体 \\
& 固体 $\rightarrow$ 気体 \\
& 電導度 \\
& 電子スペクトル \\
& 光透過率 \\
\hline
\end{tabular}

現在はフォトレジストの研究開発が進み, 超微細, 高精度 のパターン作製が可能になっているが，基本的なプロセス は変わらない。

\section{3. プリント配線板分野のレジスト1}

\section{1 フィルム型レジスト（図 1)}

プリント配線板で樹脂基板上の銅箔を回路に従ってエッ チングして，目的とする回路を形成していく。したがって， 銅䈃をエッチングする際に，回路として残す部分を覆って エッチングから防止する。プリント配線板の作製には比較 的厚膜のレジストが使われるため，古くからフィルム型レ ジストが使用されている。これはPETフィルムとポリエ
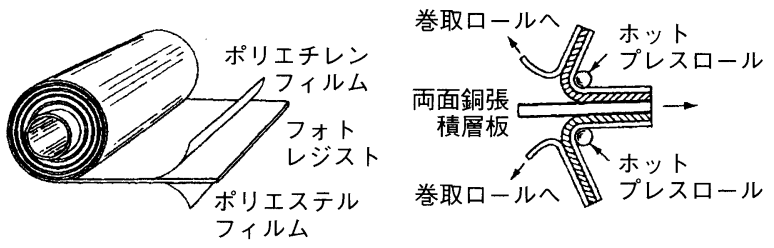

(a)

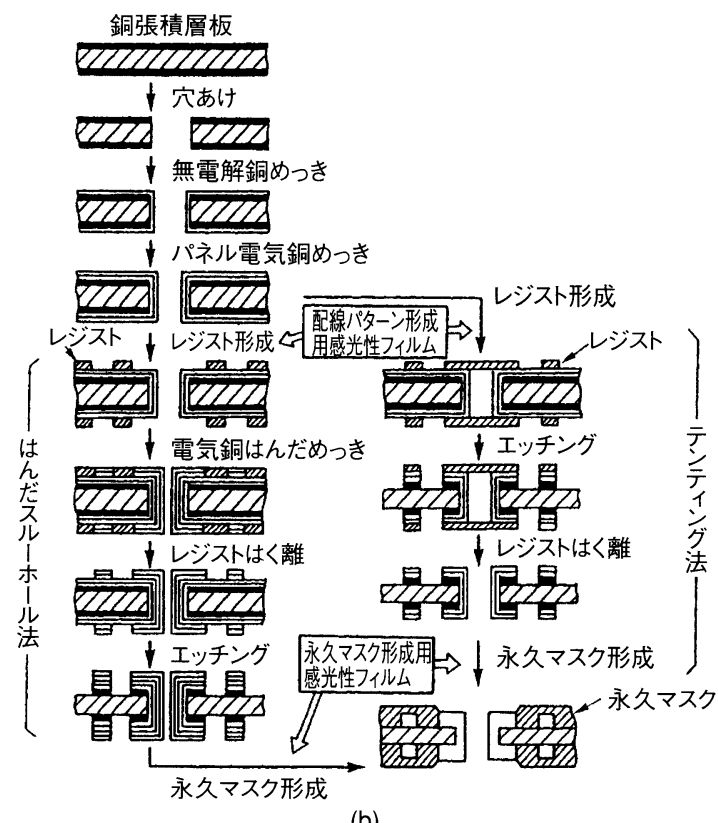

(b)

図1、フィルム型レジスト(a)とプリント配線板の製造工程(b) 
チレンフィルムに $20-75 \mu \mathrm{m}$ の厚さのレジストがサンドイ ッチされている。ベースフィルムをはがしながら銅表面に レジストをラミネートし, フォトマスク (通常, リス型フ イルムで作成されたパターンのネガ）を通して $365 \mathrm{~nm}$ 中 心とする紫外線で露光し, 場合により加熱処理または室温 放置（ホールド）した後に塩基性水溶液で現像する。残っ た膜がエッチングの防止膜となる。

\section{2 液体レジスト}

レジストが溶殽に溶かされた液体レジストでは，スピン コート, スクリーン印刷法, 電着法等で均一膜を形成して 乾燥, 露光, 現像する。プリント配線板関係ではパ夕ーン 解像度は数十〜数百 $\mu \mathrm{m}$ であるため, 数十 $\mu \mathrm{m}$ の比較的厚い レジスト膜を使用することができる。ネガ型が多く使用さ れているが，レジスト層が厚くなると体積も大きくなり， 不溶化させるため必要な光反応量も多く必要となる。反応 はフォトンにより進められるので, 結局必要なフォトン数 が多くなり見かけ上低感度化する。そのため, 厚い膜では 連鎖反応を基本とする化学反応, 光ラジカル重合型の樹脂 が採用されている。

\section{3 ソルダレジスト}

プリント配線板の製造で素子などを装着し，はんだ浴に 浸す際に，はんだの付着を防止すべき場所を高分子膜で部 分的に覆う必要がある。耐酸性などは必要ないが, $260^{\circ} \mathrm{C}$ のはんだ浴に10秒間の浸せきに耐えることなど，表 2 に示 すスペックが必要とされる。また，ソルダレジストはプリ ント配線板の完成後も表面保護膜として残るため, 高硬度 (鉛筆硬度：4-5 H) が要求される。フィルム型と溶液 型が供給されているが, 組成的には露光により架橋密度の 高い樹脂が得られる構造になっている。

\section{4 耐めっき用レジスト}

プリント配線板では, 外層パターン形成工程で感光性樹 脂が用いられる。無電解めっきと電解めっきのいずれにも 使用される。めっき層の厚みはレジスト層の厚みで制限さ れるので，厚膜レジストが必要である。また，めっき工程 は以前はアルカリ浴で長時間, 高い温度で行われるので感 光性樹脂層には大変厳しい条件であった。現在は酸性硫酸 銅浴でめっきされるようになり，そのためレジストの現像 もアルカリ水溶液で行うことができる。

表2. ソルダレジストに要求される特性2)

\begin{tabular}{ll}
\hline 特 性 & \multicolumn{1}{c}{ 規 格 } \\
\hline 硬化特性 & $\begin{array}{l}80 \mathrm{~W} / \mathrm{cm} \text { の紫外線で } 5 \mathrm{~m} / \mathrm{mm} \text { のラインスピードで硬化 } \\
\end{array}$ \\
鉛筆硬度 $4-5$ \\
密着性 & クロスカット $(100 / 100)$ \\
耐熱性 & $150^{\circ} \mathrm{C} / 30 \mathrm{~min}$ 表面劣化なし \\
& $260^{\circ} \mathrm{C} / 10 \mathrm{sec}$ 表面劣化なし \\
絶縁抵抗 & $10^{12} \Omega$ 以上 吸湿後 $10^{11} \Omega$ 以上 \\
誘電率 & $1 \mathrm{MHz} / 4.6$ 以下 \\
誘電正接 & $1 \mathrm{MHz} / 0.035$ 以下 \\
耐電压 & $12 \mathrm{kV} / \mathrm{mm}$ 以上 \\
\hline
\end{tabular}

\section{4. 超微練加工用レジスト}

半導体素子などの超微細加工は $1.0-0.1 \mu \mathrm{m}$ の超高解像度 で作成される。リソグラフィプロセスと言われ，原理的に はプリント配線板と同様な方法で造られるが，パターンの 線幅がきわめて微細なため, 露光光源もg-線 $(436 \mathrm{~nm}), \mathrm{i}$ 線 $(365 \mathrm{~nm}), \mathrm{KrF}$ エキシマレーザ $(248 \mathrm{~nm}), \mathrm{ArF}$ エキシ マレーザ $(193 \mathrm{~nm})$ と短波長光源を用いる。また，レジス 卜膜厚も $1 \mu \mathrm{m}$ から $0.5 \mu \mathrm{m}$ と薄膜化し, 厚膜の場合と異な った機構の高分子レジストが開発されている。図 2 に超微 細化の推移と使用されるレジストを示す。

素子の微細化に伴い, 露光に使用するマスク (レチクル) も微細化する。線幅が光の波長に近くなるとフレネル回折 が起こり, パターンの光学像自体が悪くなる。光学像自体 の解像度は露光光源の波長, $\lambda$ と露光光学系のレンズの開 口数，NAからつぎのように表される。

$$
\begin{aligned}
& \mathrm{R}=\mathrm{k}_{1}(\lambda / \mathrm{NA}) \\
& \mathrm{DOF}=\mathrm{k}_{2}\left(\lambda / \mathrm{NA}^{2}\right)
\end{aligned}
$$

高解像度を得るためには, レンズ系の開口数 (NA) を大 きくする方法と露光波長（入）を短くする方法があるが, NAを大きくすると焦点深度 (DOF) が短くなり，レジス ト膜厚の少しのむらでピンボケになる恐れや, また, レン ズ系の限界などから，光源の短波長化が採用されている。 線幅が $0.25 \mu \mathrm{m}$ より狭くなると, 従来の水銀灯 (g-線やi-線) では対応できず，KrFエキシマレーザ (258nm) やArFエ キシマレーザ (193nm) (図 3 ) , $\mathrm{F}_{2}$ エキシマレーザ (157nm) が使用されるようになった。そのため，0-ナフ

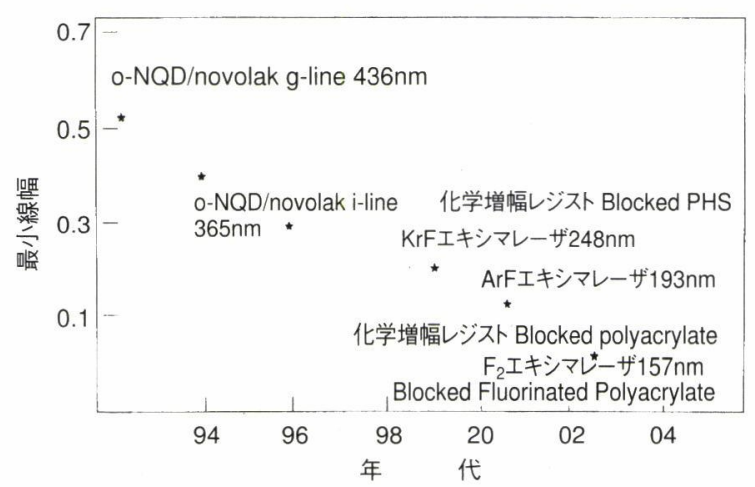

図2. 微細加工の推移 ${ }^{3}$
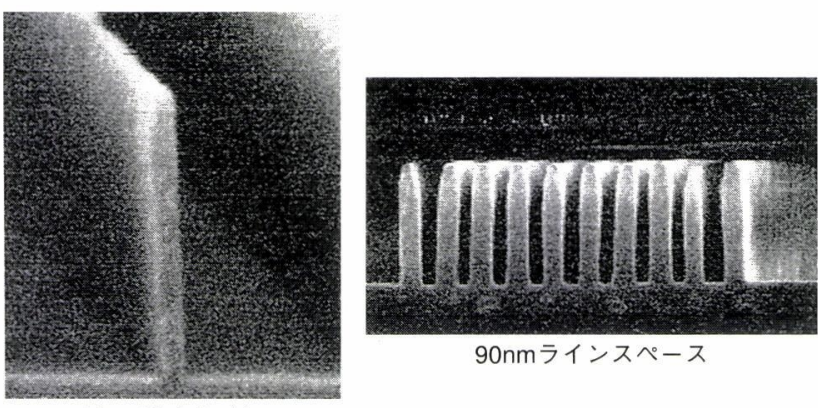

90nmラインスペース

40nm孤立ライン

図3. ArFエキシマレーザ光 $(193 \mathrm{~nm})$ により転写したライン\& スペースパターン (写真提供 ASET 森 重恭氏) 


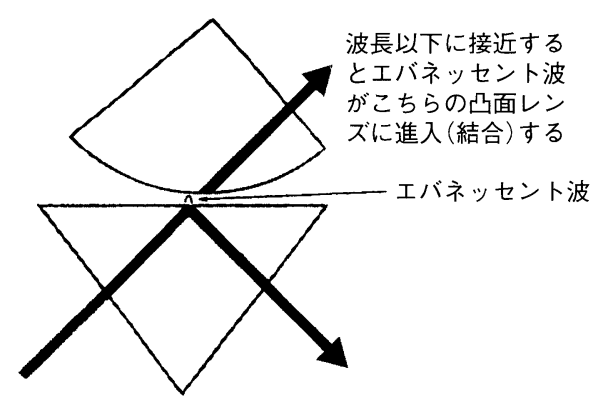

(a)

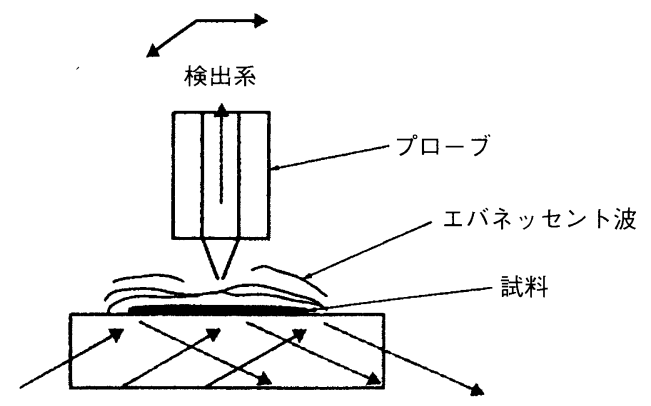

(b)

図4.エバネッセント波による微細パターン露光法4)

トキノンジアジドーノボラック樹脂系レジストでは光透過 率の低さからパターン形成が困難となり, $\mathrm{ArF}^{2} \mathrm{~F}_{2}$ レーザ 光を透過するポリマーを設計し，そのポリマーをベースと して，化学増幅型と言われる新規機構によるレジスト材料 が開発された。この方法で高解像度 $(0.13 \mu \mathrm{m})$ のパター ン転写が可能になった。さらに，高解像度を得るために $13 \mathrm{~nm}$ のX-線で露光するEUVリソグラフィの研究もすでに 進められている。

将来技術としてシリコンウエハ表面の水酸基を利用し， 必要部分にのみレジスト膜を形成させるビルドアップ法 や，プリズムの全反射光を得る際に洩れる光，エバネッセ ント波を利用する近接場光学系で露光する試みも行われて いる（図 4 ）。エバネッセント波は波動性がなく回折が起 こらないため数 $n m$ の極微パターン転写の可能性が期待さ れる。

\section{5. 高耐熱性感光性樹脂}

\section{1 耐熱構造}

耐熱性の感光性樹脂としては, エポキシ樹脂, ポリシロ キサン，ポリアミドイミドをべースにしたもの等が検討さ れ, それぞれの用途に使用されているが, 最近, 半導体素 子のバッファ層や多層配線板の層間絶縁膜として, 感光性 ポリイミドやポリオキサゾール等の研究開発が進んでい る。従来, 優れたスペックを有している非感光性のポリイ ミドにフォトレジストを用いてパターン形成し，アミン化 合物でポリイミドをエッチングする方法が行われていた。 この方法は非常に長いプロセスが必要であるが, 感光性の ポリイミドを使用すると, 工程が著しく短縮される(図 5 )。

これまでに耐熱性樹脂として知られている熱可塑性樹脂 に感光性を付与したタイプの樹脂が多い。耐熱性は高温度

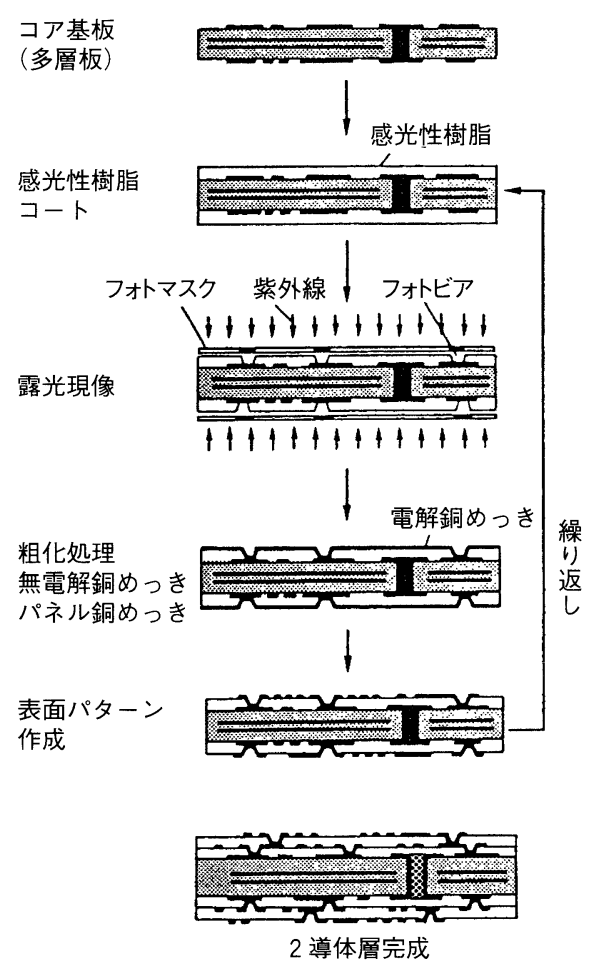

図5. 而熱性樹脂によるフォトビア・パネルめっきによる ビルドアップ法 ${ }^{5}$

で変形や劣化が起こりにくい性質を言い，物理的耐熱性と 化学的耐熱性に分類される。前者は熱により高分子の分子 構造自体は変化しなくても熱軟化で変形する性質が，また 後者は高分子の化学結合の切断で分子量が低下し, 分子構 造の変化が生じる性質が，耐え得る温度の高さで定義され る。物理的耐熱性はガラス転移温度や軟化温度（Tm）を 高くすることにより達成され, 融解のエンタルピー $(\Delta \mathrm{H})$ が大きく, 融解のエントロピー $(\Delta \mathrm{S})$ が小さくなるよう な分子構造を設計すればよい。

化学的な耐熱性は高分子を構成する結合のエネルギが大 きい構造［共役系を広げる］に設計することや，ラダー構 造として結合が熱破壊されても分子量が低下する確率を下 げる方法で達成できる。ただし，材料として用いるときに は耐熱性と同時に溶解性, 成膜性, 密着性, 誘電率, 膨張 係数の他，多くの特性を併せ持つ必要があるので実際の分 子設計は難しい。これらの中で電子材料として要求される 低誘電率化と線膨張係数は重要な課題である。ポリイミド は誘電率が高い高分子であるので, 低誘電率化のために自 由体積率を大きくすると,ガラス転移温度の低下が生じる。 したがって相反する性質を克服しなければならない。骨格 にバルキーなセグメントを導入する方法，ポリイミド膜に ナノボイドを形成させる方法などが検討されており，両者 の妥協点を見出す努力が行われている。

\section{6. 感光性樹脂の化学}

\section{1 光架橋}

分子量が比較的大きく溶剤に溶かして塗布することので 
きる線状高分子に光反応性の感光基を主鎖，側鎖構造とし て有するもの, あるいは単純に光反応性の架橋物質を混合 した感光性樹脂である。この感光基, あるいは感光性物質 が光を吸収して高分子や感光基同士が反応結合し，その結 果線状高分子が架橋構造に変化し溶剤に不溶化（ゲル化） する。表 3 に主な例を示す。古くは天然高分子と重クロム 酸塩を混合したものが使われていた。1950年代に，けい皮 酸をPVAに導入した感光性樹脂がコダック社からKPRの 商品名で上市されフォトレジストの呼び名が使われるよう になっだ。けい皮酸が光二量化してッルキシン酸を生成 する反応を利用している。この光二量化の反応は短波長光 （－270nm）を要するため三重項－三重項エネルギ移動に よる増感剤を使用し $365 \mathrm{~nm}$ の光で反応するようにした（図 6 )。

表3. 主な光架橋型フォトレジストの構成成分 (a) 高分子に光架橋物質を混合する夕イプ

\begin{tabular}{ll}
\hline \multicolumn{1}{c}{ 高分子化合物 } & \multicolumn{1}{c}{ 光架橋剂 } \\
\hline 光架橋剤をブレンドするタイプ & \\
ポリビニルアルコール & 重クロム酸ナトリウム \\
& ジアゾ樹脂 \\
ポリイソプレン & アジド化合物 \\
ノボラック樹脂 & アジド化合物 \\
ポリアクリルアミド & 水溶性アジド化合物 \\
クレゾールノボラック & o-ナフトキノンジアジド \\
樹脂 & -5ースルフォン酸エステル \\
\hline
\end{tabular}

(b) 高分子の構造として光官能基を含むタイプ

ポリビニルシンナメート

ポリ (p-アジドベンゾエート)

ポリエステル（p-フェニレンジアクリル酸ージエタノールアミン）

(a)

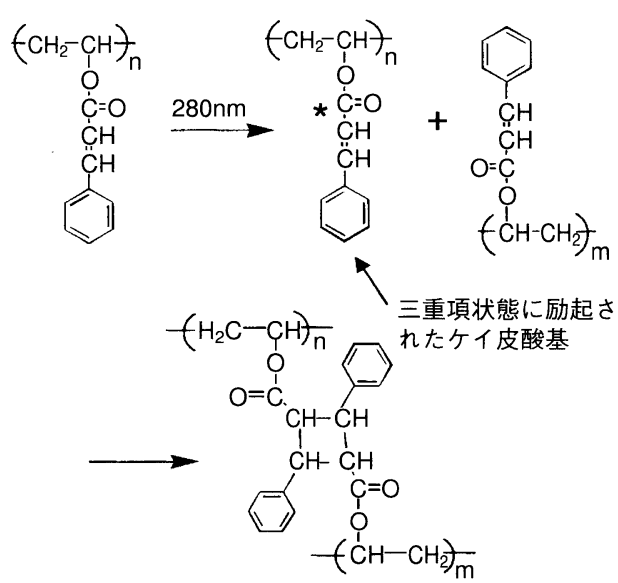

(b)

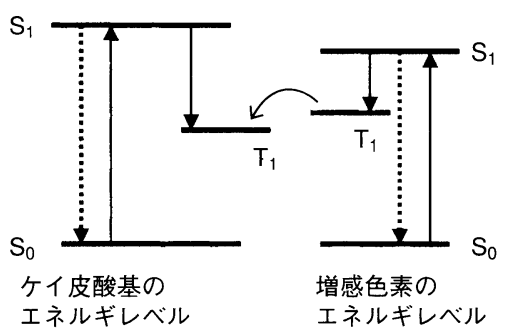

図6. ポリビニルケイ皮酸の光二量化(a)と三重項一三重項 エネルギ移動機構による分光増感のモデル(b)

\section{2 光重合}

アクリレートモノマーは熱ラジカル重合開始剤を少量加 えて加熱するとラジカル重合（連鎖反応）を起こして分子 量の大きい高分子化合物を生成し, PMMAなどのプラス チックを与える。これと同様の原理で, 上のモノマーに光 ラジカル重合開始劑を加えて露光すると重合が生じて高分 子が生成する。モノマーは液体が多いので，これを露光す ると固体に変化する。露光によるこの変化はさまざまなと ころに利用されて, 光ラジカル重合型感光性樹脂とよばれ ている。このタイプの感光性樹脂は連鎖反応を含むため, 照射した光のフォトン数以上の単位反応を行うので, 体積 の大きい樹脂層を硬化させるのに優れている。

実際に使用するにはアクリレートモノマーは液体で揮発 性の液体のため, そのままでは使用できない。通常, 適当 な分子量のオリゴマー（バラスト）にモノマーを 1 分子か ら数分子, 化学的に組み込み, 反応性オリゴマー（プレポ リマーともいう）の形にして使用する（図 7 )。

光重合の素反応はつぎのように表される。

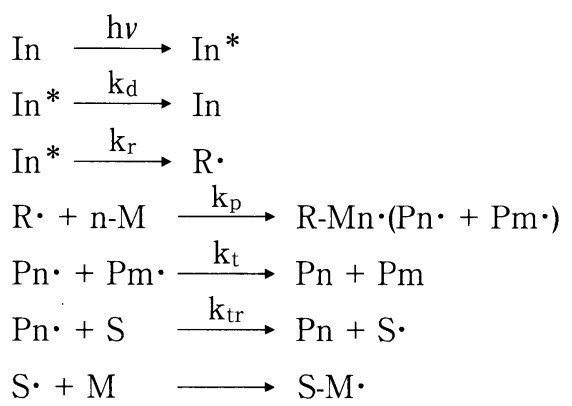

この素反応からモノマーの重合速度 (コンバージョン速度) $\mathrm{dM} / \mathrm{dt}$ は次式で表される。

$\mathrm{d}[\mathrm{M}] / \mathrm{dt}=\mathrm{k}_{\mathrm{p}} / \mathrm{k}_{\mathrm{t}}^{1 / 2}[\mathrm{M}]\left[10^{3} \mathrm{I}_{0 \lambda} \Phi \mathrm{fL}^{-1}\left\{1-\exp \left(-2.3 \varepsilon_{\lambda}[\mathrm{In}] \mathrm{L}\right)\right\}\right]^{1 / 2}$

ここで, $-2.3 \varepsilon_{\lambda}[\operatorname{In}] \mathrm{L}$ が小さい場合は

$\mathrm{d}[\mathrm{M}] / \mathrm{dt}=\mathrm{k}_{\mathrm{p}} / \mathrm{k}_{\mathrm{t}}{ }^{1 / 2}[\mathrm{M}]\left(2.3 \times 10^{3} \mathrm{I}_{0 \lambda} \mathrm{f} \Phi[\mathrm{In}]\right)^{1 / 2}$

ここで, InおよびIn*は重合開始剂の基底状態と励起状 態を示す。また, $\mathrm{k}_{\mathrm{d}}, \mathrm{k}_{\mathrm{r}}, \mathrm{k}_{\mathrm{p}}, \mathrm{k}_{\mathrm{t}}, \mathrm{k}_{\mathrm{tr}}$ は重合開始剤の失活, ラジカル形成, 成長, 連鎖重合の停止, 連鎖移動の速度定 数を示す。 R・, M, M, は開始ラジカル, モノマー, お よびモノマーの成長ラジカルを示す。

$\mathrm{dM} / \mathrm{dt}$ この機構の感光性樹脂の感度に対応させると， 材料中の各成分の感度に対する役割を定性的に判断するこ とができる。

プレポリマーは感度と光硬化した樹脂の物理的および機 械的な特性に, 開始剤は感光波長と感度を支配する。特に

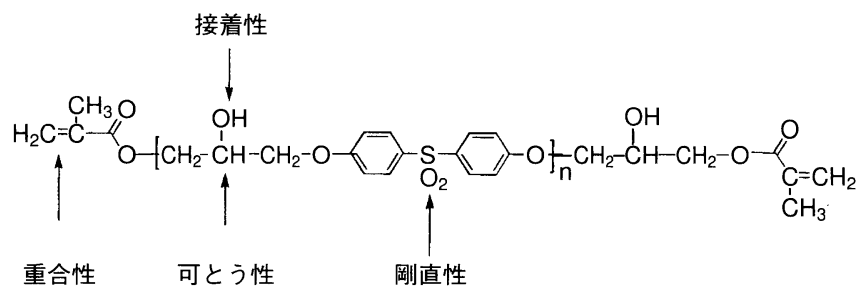

図7. 光ラジカル重合型のプレポリマーの設計例 
感光波長は開始剤の感光波長, 通常開始剤の吸収スペクト ルに依存する。例えば, $365 \mathrm{~nm}$ の光で露光する場合はこの 波長に吸収をもつ開始剤を用いることはいうまでもない。 また, 可視光レーザで露光する場合はレーザ光の波長 （ $\mathrm{Ar}^{+}$レーザでは488nm，514.5nm）を吸収する開始剤が必 要になる。単独で可視光を吸収する開始剤は少ないため, 増感色素とラジカル発生剤とを組み合わせる 2 分子系を用 いる必要がある。また, 感光層が薄膜の場合と厚膜の場合 では，分子吸光係数を選択することが必要である。

開始剂は感度の他，プリント配線板のように金属銅では 反応して感光層の寿命に影響を与えるものや，逆に銅表面 との接着性を改善するものもあり, 素反応だけではわから ない因子が多い。また，樹脂が重合するに従い硬くなり， ガラス転移点が高くなると同時に高分子としての自由体積 率が小さくなる。この場合, 開始剂ラジカルの分子占有体 積が樹脂層内部での拡散を抑制することになり, 重合が完 結する前に停止してしまうこともある。開始ラジカルの分 子占有体積の小さい開始剤を選択する必要がある。ポリマ 一のガラス転移点での自由体積率とラジカル種の分子占有 体積との関係から, 重合反応が停止することがある。した がって，このような場合には体積の小さいラジカル種を用 いなければならない。高分子マトリックスの効果（ガラス 転移点）を考慮に入れた場合の感度はつぎのようになる7。

$$
\begin{aligned}
& \mathrm{V}_{\mathrm{f}}=\mathrm{V}_{\mathrm{fg}}+\alpha_{\mathrm{c}}\left(\mathrm{T}-\mathrm{T}_{\mathrm{gc}}\right) \\
& \mathrm{E}_{\mathrm{m}}=\mathrm{d}\left(1 / \mathrm{T}_{\mathrm{r}}\right) \\
& \mathrm{E}_{\mathrm{m}}=\mathrm{A} \exp (-\mathrm{E} / \mathrm{RT})\left[\alpha_{\mathrm{p}}\left(1-\mathrm{V}_{\mathrm{m}}\right)\left(\mathrm{T}-\mathrm{T}_{\mathrm{gp}}\right)+\left(\mathrm{V}_{\mathrm{m}} \alpha_{\mathrm{m}}\right)\left(\mathrm{T}-\mathrm{T}_{\mathrm{gm}}\right)\right.
\end{aligned}
$$
ただし,

$\mathrm{V}_{\mathrm{f}} \quad$ : 感光層の温度Tでの自由体積率

$\mathrm{V}_{\mathrm{fg}}$ : 感光層のガラス転移点での自由体積率 :

$\mathrm{V}_{\mathrm{m}}$ : モノマーの体積分率

$\mathrm{T}_{\mathrm{r}} \quad$ : 感光層の光透過率

$\mathrm{E}_{\mathrm{m}}$ : 感度

$\mathrm{T}_{\mathrm{gc}}$ : 感光層のガラス転移点

$\alpha_{\mathrm{c}} \quad$ : 感光層の熱膨張係数過剰分

$\alpha_{\mathrm{p}} \quad$ : ポリマーの熱膨張係数過剩分 $\left(4.58 \times 10^{-4}\right)$

$\alpha_{\mathrm{m}}$ : モノマーの熱膨張係数過剰分 $\left(1 \times 10^{-3}\right)$

$\mathrm{T}$ : 絶対温度

$\mathrm{T}_{\mathrm{gp}} \quad$ : バインダーポリマーのガラス転移点

$\mathrm{T}_{\mathrm{gm}}$ : モノマーのガラス転移点

E：活性化エネルギ

$\mathrm{R}$ : 気体定数

感光層が厚い場合は照射光がなるべく底辺まで到達する ような設計が行われなければならない。露光波長，入での 開始剂の分子吸光係数 $\varepsilon_{\lambda}$ が大きすぎると光が底辺まで十分 に届かないことになる（図 8）。

- 光重合開始剂

光重合型の感光性樹脂で開始剤は光の取り入れ口である ので, 反応の開始にとり, 最も大事な組成物である。感度,
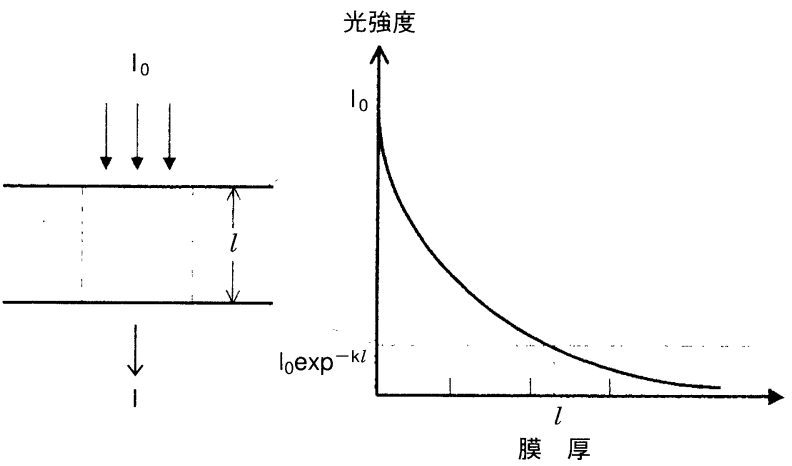

図8. 感光層の厚さ方向の光強度の変化

感光波長, 基板との接着性, 安全性などを決める組成であ る。開始剤は非常に多く発表されているが実用化されてい るのはあまり多くない。黄変性, モノマーとの相溶性, 貯 蔵安定性の他に様々な性質が要求される。

1 分子系と 2 分子系がある。前者は単独で開始種を生成 するタイプ, 後者は単独でもよいが, 他の適当な促進剤や 色素と組み合わせて使う。その場合, 感度が著しく高くな ったり，可視光で重合を開始したりする。レーザ記録やホ ログラム記録に使用する際に可視光に感光性を伸ばす際に 利用される。

・単分子型重合開始剂

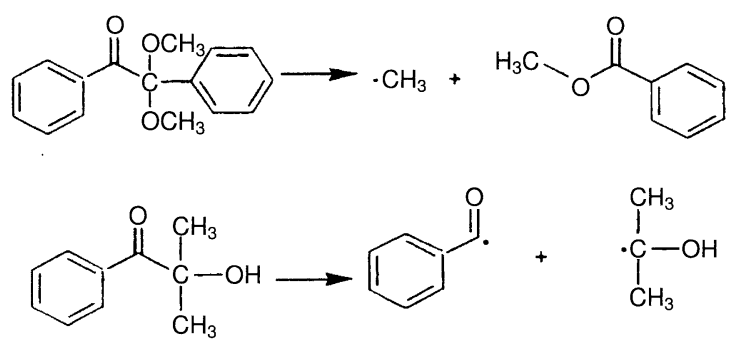

- 2 分子系開始剂

ラジカル発生剤, 酸発生剂のいずれも, 特定の化合物を 併用すると単独で使用する場合よりも著しく高感度化し, 単独では感光しない波長光に感光するようになる。この高 感度化はいくつかの機構によることが知られている。チオ キサントンは単独で光ラジカル発生郕として使用される が，ジメチルアミノ安息香酸エステルと組み合わせると開 始効率が高くなり，よく使用される。その機構は次のよう に考えられている。
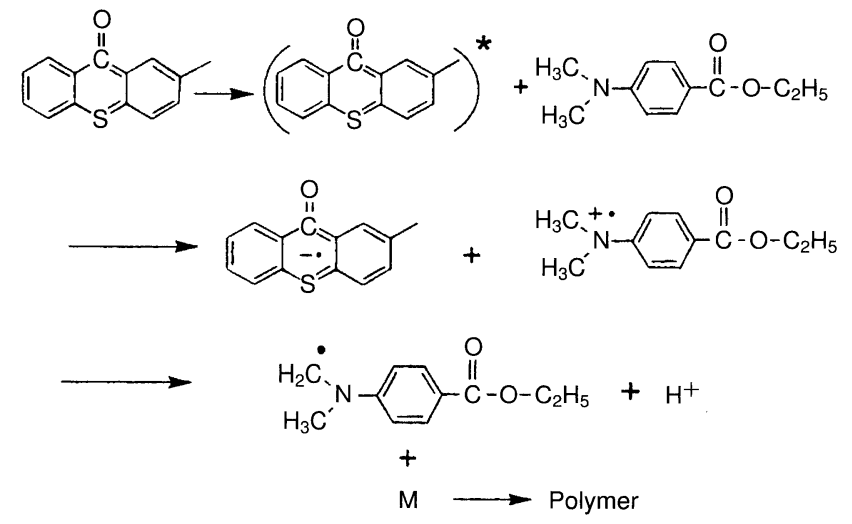

増感剤，あるいは基質が励起すると電子移動，すなわち 


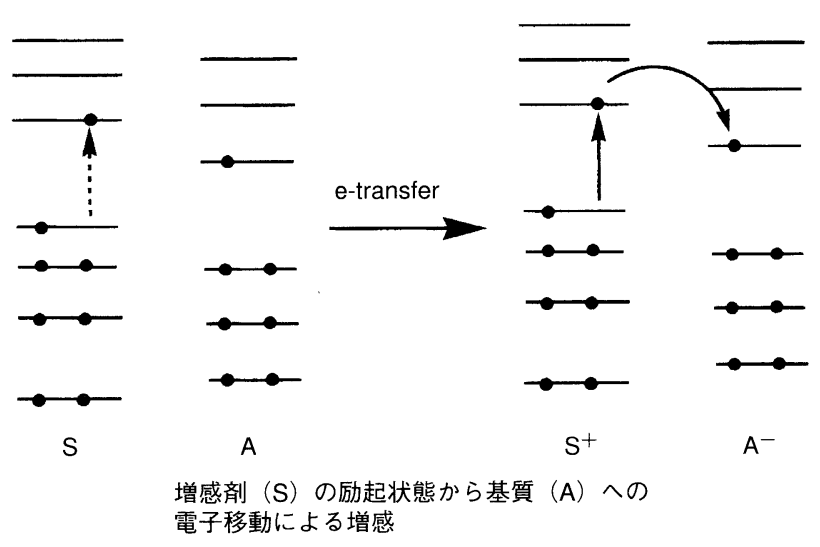

図9. 色素の励起状態から基質への電子移動による増感の機構

レドックス反応が起こり，間接的に分解が生じる（図 9 )。 上の例ではジメトキシアントラセン部の励起状態から電子 が移動するが，この場合，電子移動に伴う自由エネルギ変 化 $(\Delta \mathrm{G})$ がー $5 \mathrm{kcal} / \mathrm{mol}$ よりさい場合には, 拡散律速で 電子移動が起こる。 $\Delta \mathrm{G}$ は次式で求められている。

$$
\Delta \mathrm{G}=\left[\mathrm{E}^{\mathrm{OX}}{ }_{1 / 2}\left(\mathrm{~S} / \mathrm{S}^{+}\right)-\mathrm{E}^{\mathrm{RED}}{ }_{1 / 2}\left(\mathrm{~A}^{-} / \mathrm{A}\right)\right]-\mathrm{E}\left({ }^{1} \mathrm{~S}^{*}\right)-\mathrm{e}^{2} / \mathrm{R} \varepsilon
$$

ここで, $\mathrm{E}_{1 / 2}^{\mathrm{OX}}$ は電子供与体の酸化電位, $\mathrm{E}_{1 / 2}^{\mathrm{RED}}$ は電子受 容体の還元電位, $E\left({ }^{1} \mathrm{~S}^{*}\right)$ は最低励起エネルギ（一重項から 生じる場合は吸収の 0,0 帯のエネルギ，三重項から生じ る場合は三重項エネルギ), $\mathrm{e}^{2} / \mathrm{R} \varepsilon$ は電子移動後のクーロン 力のエネルギを表す。

\section{3 光溶解性変化}

高分子の分子量は変化しないが, 内在する官能基が光に より変化し, 溶解性などの変化が起こる機構である。半導 体など超微細加工のレジストとして，g-線およびi-線用に はクレゾール型ノボラック樹脂にo-ナフトキノンジアジ ド- 5 -スルフォン酸エステル（o-NQD）を添加したポジ型 レジストが使用されているが，最もよく知られたポジ型レ ジストである。これは図10に示すようにo-NQDがノボラ ック樹脂のアルカリ水溶液への溶解性を阻止し, 露光によ りo-NQDが光分解してインデンカルボン酸となると逆に 溶解性を促進させる効果を利用したものである。クレゾー ル型ノボラック樹脂の性質から非常に高解像度のパターン (0.35 $\mu \mathrm{m}$, DRAMで64Mbit程度まで) が得られ, 優れたレ

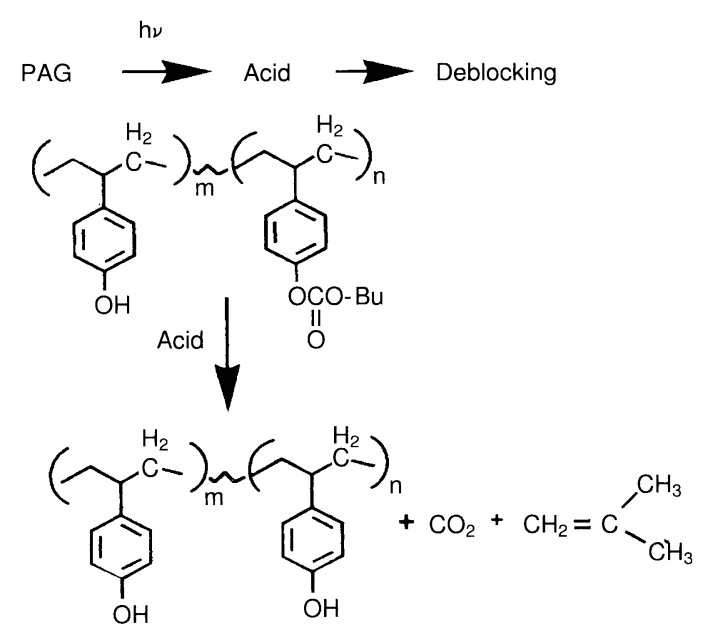

図11. 化学増幅型レジストの反応機構

ジストである。

しかし，高解像度化のために $\mathrm{KrF}$ エキシマレーザ (248nm) が光源として採用されるとo-NQD-ノボラック樹 脂レジストが光透過率の低さから使用できなくなった。そ のため, ノボラック樹脂の代りに $248 \mathrm{~nm}$ 光に高い透過率を もつポリマーと感光物質を開発せざるを得なくなった。現 在, 化学増幅型とよばれる新規レジストが使用されている。 これは, p-ヒドロキシポリスチレン（この高分子は $\mathrm{KrF}$ キシマレーザの $248 \mathrm{~nm}$ 光に比較的高い透過率を示す）の水 酸基の一部をtert-ブトキシカルボニル基（t-BOC）でブロ ックした高分子に光酸発生剂を加えたレジストである。図 11 に示すように, 露光により強酸が発生し, 加熱工程 (PEBといわれる) でブロックしているt-BOCを外す。そ の結果, その部分の水酸基が増加してアルカリ溶解性が大 きくなり, 現像で露光部のみ溶解除去され, ポジパターン が形成される9”。の機構では光で発生した酸の量がレジ スト層の表面付近と底部で異なっても, 後のPEB工程で拡 散のため平均化されるために垂直なパターン形成が可能と 考えられている。

また，193nmの光源に対しては芳香族環が存在すると透 過率が低下するため, 使用できなくなる。しかし, 素子作 製工程でプラズマエッチングがあり，これに耐性を有する

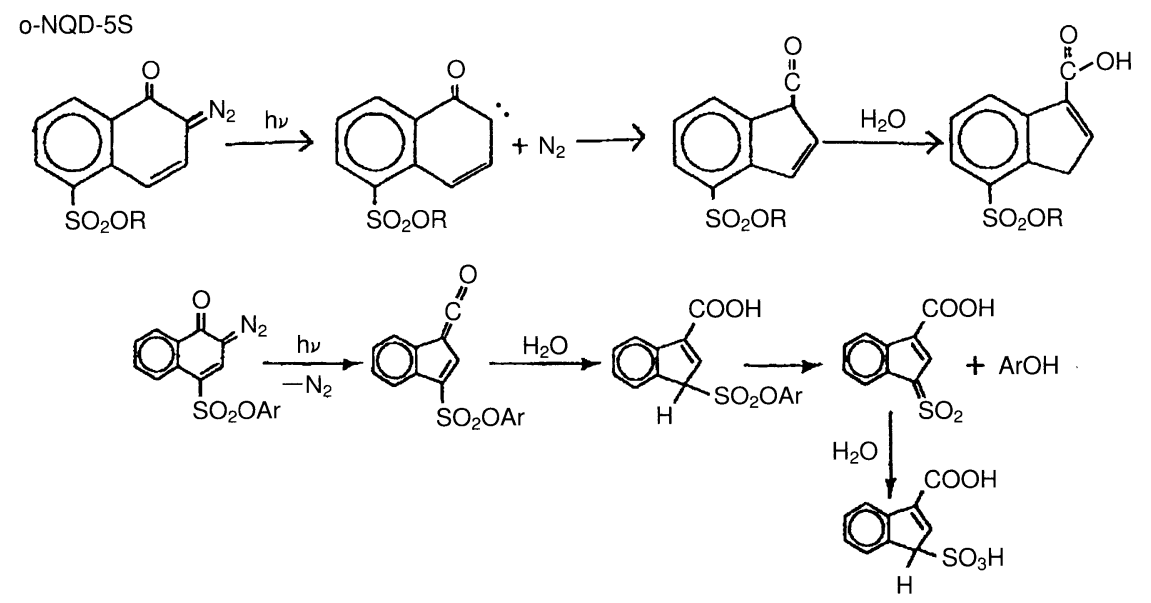

図10. o-ナフトキノンジアジド- 5 -スルフォン酸エステルおよび- 4 -スルフォン酸エステルの光反応 

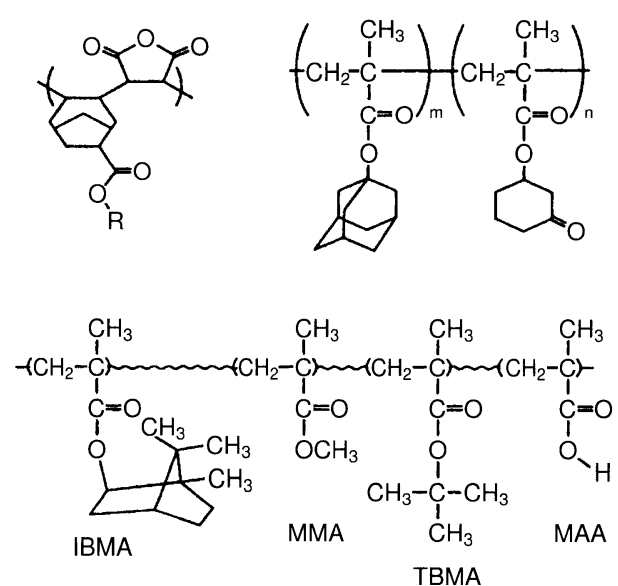

(a)
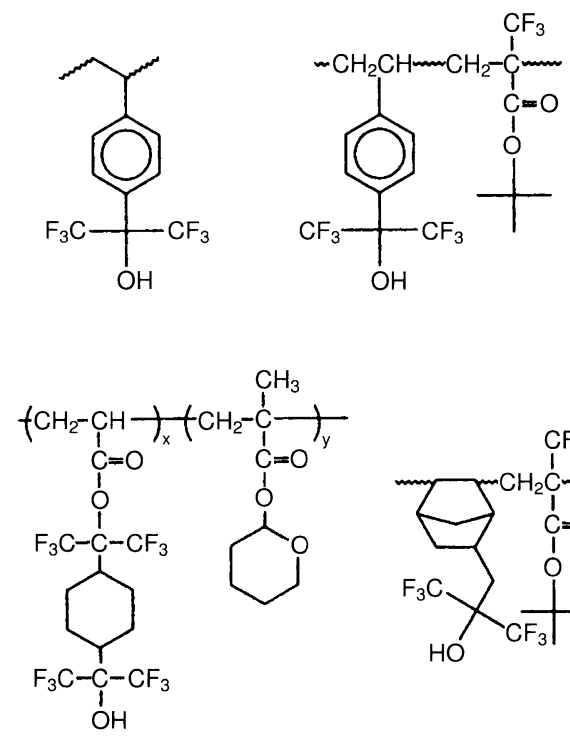

(b)

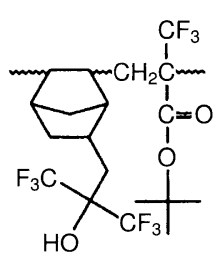

図12. ArF $(193 \mathrm{~nm})(\mathrm{a})$ と $\mathrm{F}_{2}(157 \mathrm{~nm})(\mathrm{b})$ エキシマレーザ リソグラフィ用のベースポリマーの例

必要がある。そのため, 脂環構造を導入することにより上 の相反する要求に応えている ${ }^{10 r 15)}$ 。

現在は将来, 必要になるとみられている, $\mathrm{F}_{2}$ エキシマレ ーザの $157 \mathrm{~nm}$ 光に使用可能なレジストの研究が行われてい $ろ^{16120)}$ (図12)。

・光酸発生剂

上で述べた化学増幅機構では光で強酸を発生する物質が 必要になる。光照射でルイス酸やブレンステッド酸を発生 する感光性物質であるスルフォニウム塩やヨードニウム塩 は, J.V.Crivelloらによって広範に開発された 例としてトリフェニルスルフォニウム塩はつぎのように分 解して酸を生成する。

$$
\begin{aligned}
& \mathrm{Ar}_{3} \mathrm{~S}^{\oplus} \mathrm{X}^{\ominus} \underset{\mathrm{RH}}{\stackrel{\mathrm{h} v}{\longrightarrow}} \mathrm{Ar}_{2} \mathrm{~S}+\mathrm{Ar}+\mathrm{R}+\mathrm{HX} \\
& \mathrm{Ph}_{2} \mathrm{I}^{\oplus} \mathrm{X}^{\ominus} \stackrel{\mathrm{h} v}{\longrightarrow} \mathrm{PhI}+\mathrm{Ph}+\mathrm{R}+\mathrm{HX} \\
& \mathrm{X}: \mathrm{AsF}_{6}{ }^{\ominus} \mathrm{CF}_{3} \mathrm{SO}_{3}{ }^{\ominus}
\end{aligned}
$$

微細加工の分野では短波長光で露光するため, 300nmよ り短波長光に感光する酸発生剤が数多く合成されている。
しかし，近紫外や可視領域で使用する感光性樹脂にも使用 できる。そのためにこれら長波長光に感光する酸発生剂も 必要である。i-線，g-線，可視光線に感光する酸発生剂の 例を下に示す。

ジフェニルヨードニウム・ $\mathrm{PF}_{6}$ は単独では300nm付近の 光が必要であるが, ジメトキシアントラセン-2 -スルフォ ン酸をアニオンにするとi-線で反応しスルフォン酸が生成 する。これはアニオンが励起状態からジフェニルヨードニ ウムカチオンに電子移動が生じて分解するためと考えられ ている ${ }^{22) \sim 24) 。 ~}$

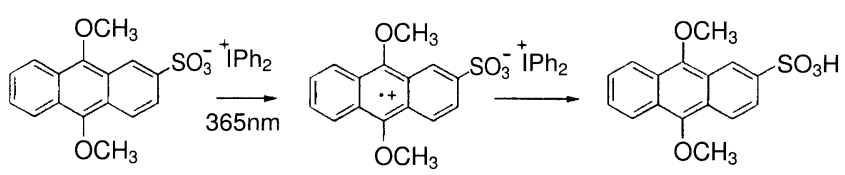

IBMのG.W.Wallaffらはdiphenyliodonium hexafluoro antimonateに対 し 1,8-dimethoxy9,10-bis(phenylethynyl) athraceneを増感剤として用い，488nm，514.5nmの可視光 に感光する酸発生剂を見出している ${ }^{25)}$
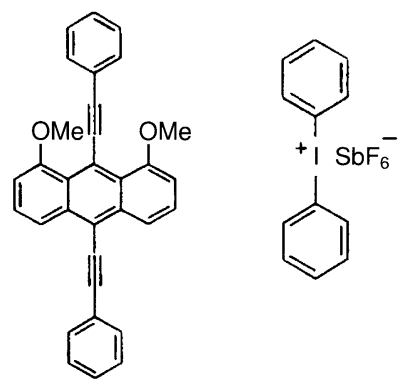

\section{4 光架橋切断 (VE-VE)}

ビニルエーテル基はプロトンを開始種としてカチオン重 合を起こすことが知られているが，プロトン性水酸基がビ ニル基に付加してアセタール構造を形成する反応も行う。 一方，アセタール結合は強酸の存在で容易に切断される。 この反応を利用すると, 多官能ビニルエーテルモノマーと 光酸発生剂を用い，フェノール基またはカルボキシル基を 含む高分子はどれでもこれら 3 成分でポジ型感光性樹脂に 変換できる ${ }^{26)}$ 。

・ビニルエーテルによる架橋と酸分解に基づくレジスト<smiles>C=COCOOC=C</smiles>

この反応を利用して，可視光レーザによる走查型のプリ ント配線板用フィルムレジストが開発されている。組成と

(1)


$\mathrm{Ar}^{+}$Laser(488nm)

増感色素

励起状態 増感色素
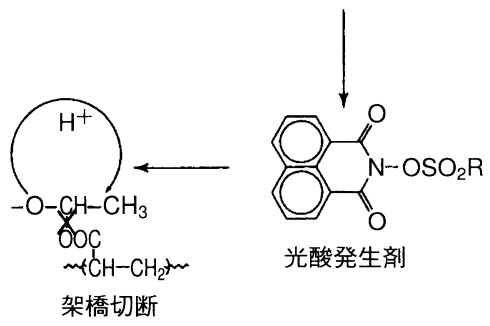

光酸発生刘

図13. Arイオンレーザ走査露光用のフィルム型レジストの開始剈 $(\text { 光酸発生剤 })^{27}$

特性を図13に示す ${ }^{27}$ 。

\section{5 光解重合}

光照射によりモノマーに戻るタイプの高分子化合物で PMMAが電子線でモノマー化するのはよく知られている。 また，ポリフタルアルデヒドはアニオン重合により $-80^{\circ} \mathrm{C}$ で合成されるが，天井温度が低いため常温では解重合して モノマーに戻る。しかし，末端をアセチル基でブロックす ると $150^{\circ} \mathrm{C}$ 位まで安定になる。この高分子に光酸発生剂を 加えた薄膜に光照射すると, 発生した酸が末端のブロック を外し，解重合してモノマーの気体になる。

\section{7. おわりに}

感光性樹脂の応用は今後も一層の広がりを示すと予想さ れる。その結果，さまざまな性能の感光性樹脂，いろいろ な使い方が現れるのは論を待たない。本稿では主としてレ ジストに関連した感光性樹脂について概略を記したが，ナ ノテクノロジの時代に入り一層重要な技術になると考えら れる。

(2001.11.2-受理２001.11.20-再受理)

\section{文献}

1) “フォトポリマーハンドブック”, フォトポリマー懇話会編, 工業調查会, 1989

2) 府川通博, 中村宗一，蛇川 洋 : “光 - 放射線硬化技術”, p.256，大成社， 1985

3) 中瀬 真：“半導体集積回路用レジスト材料ハンドブック”, 第 1 章, リアライズ出版, 1996

4) “レーザの科学”, レーザ技術総合研究所編, p.31, 丸善, 1999

5) 高木 清： “ビルドアップ多層プリント配線板技術”, 日刊 工業新聞社, 1999

6) L.M.Minsk, J.G.Smith, W.P.VanDeusen, J.F.Wricht : "Photosensitive Polymers I. Cinnamate Esters of Poly (Vinyl Alcohol) and Cellulose", J.Appl.Polym.Sci., No.2, p.302, 1959

7) M.F.Molire : “A Free-Volume Model for Photopolymerizable/Crosslinkable Dry-Film Systems", J. Polym. Sci.,

Polym Chem. Ed., 20, pp.847-861, 1982

8) D.Rhem and A.Weller: "Kinetics of Fluorescence Quenching by Electron and H-Atom Transfer", Isr.J. Chem., No.8, p.259, 1970

9) M.J.Bowden : "A Perspective on Resist Materials for FineLine Lithography", Chapter 3, Materials for Microlithography. Ed. L.F.Thompson, C.G.Willson and J.M.J. Frechet, ACS Symposium Series 266, pp.39-117, 1984

10) 後河内 透, 内藤卓也：“半導体集積回路用レジスト材料ハ ンドブック”，第 6 章, p.99, リアライズ社, 1996

11) R.D.Allen, G.M.Wallaff, R.A.GiPietro, D.C.Hofer, R.R.Kunz : "Single Layer Resists with Enhanced Etch Resistance for 193 nm Lithography", J. Photopolym. Sci. Technol., Vol.7, No.3, p.507, 1994

12) R.D.Allen, G.M.Wallaff, R.A.GiPietro, D.C.Hofer : "Resolution and Etch Resistance of A Family of $193 \mathrm{~nm}$ Positive Resists”, ibid., Vol.8, No.4, p.623, 1995

13) U.Okoroanyanwu, T.Shimokawa, J.Byers, C.G.Willson : "Alicyclic Polymers for 193nm Resist Applications: Synthesis and Characterization", Chem. Mater. Vol.10, No.11, pp.3319-3327, 1998

14) T.Hattori, Y.Tsuchiya, Y.Yokoyama, H.Oizumi, T.Morisawa, A.Yamaguchi, H.Shiraishi : "Micro-Swelling-Free Negative Resists for ArF Phase-Shifting Lithography Utilizing Acid-Catalyzed Intramolecular Esterification", J. Photopolym. Sci. Technol., Vol.12, No.3, pp.537-544, 1999

15) F.M.Houlihan, T.Wallow, A.Timko, E.Neria, R.Hutton, R.Cirelli, O.Naramasu, E.Reichmanis: "Recent Advances in $193 \mathrm{~nm}$ Single-Layer Photoresists Based on Alternating Copolymers of Cycloolefins", SPIE 3049, pp.84-91, 1997

16) T.M.Bloomstein, N.W.Horn, M.Rothschild, R.R.Kunz, S.T.Palmaccl, R.B.Goodman: "Lithography with $157 \mathrm{~nm}$ Laser", J. Vac. Sci. Technol. B15(6), pp.2112-2116, 1997

17) H.Ito, G.M.Wallraff, N.Fender, P.J.Brock, C.E.Larson, H.D.Truong, G.Breyta, D.C.Miller, M.H.Sherwood and R.D.Allen : "Novel Fluoropolymers for Use in $157 \mathrm{~nm}$ Lithography", J. Photopolym. Sci. and Technol., Vol.14, No.4, pp.583-594, 2001

18) C.Brodsky, J.Byers, W.Conley, R.Hung, S.Yamada, K.Patterson, M.Somervell, B.Trinque, H.V.Tran, S.Cho, T.Chiba, S.H.Lin A.Jamieson, H.Johnson, T.V. Heyden, C.G.Willson : “157nm Resist Materials : Progress Report”, J. Vac. Sci. Technol. B18(6), pp.3396-3401, 2000

19) H.Ito, G.M.Wallraff, N.Fender, P.J.Brock, C.E.Larson, H.D.Truong, G.Breyta, D.C.Miller, M.H.Sherwood R.D.Allen : "Novel Fluoropolymers for Use in 157nm Lithography", J. Photopolym. Sci. and Technol., Vol.14, No.4, pp.583-594, 2000 
20) Y.C.Bae, K.Douki, T.Yu, J.Dai, D.Schmaljohann, S.H.Kang, K.H.Kim, H.Koerner, W.Conley, D.Miller, R.Balasubramanian, S.Holl, C.K.Ober: "Rejuvenation of 248nm Resist Backbones for 157nm Lithography”, J. Photopolym. Sci. Technol, Vol.14, No.4, pp.613-620, 2001

21) James.V.Crivello: "The Discovery and Development of Onium Salt Cationic Photoinitiator", J. Polym. Sci., Part A, Polym. Chem., No.37, pp.4241-4254, 1994

22) T.Yamaoka, H.Adachi, K.Matsumoto, H.Watanabe, T.Shirosaki : "Photochemical Dissociation of p-Nitrobenzyl 9, 10-Dimethoxyanthracene-2-sulfonate via Intramolec-ular Electron Transfer", J. Chem. Soc., PARKIN TRANS. 2, pp.1709-1714, 1990

23) K.Naitoh, T.Yamaoka : "Photochemical Dissociation of pNitrobenzyl Sulfonate Esters via an Intramolecular Electron Transfer", J. Chem. Soc., PARKIN TRANS. 2, pp.663-669, 1992

24) K.Naitoh, T.Yamaoka, A.Umehara : "Intra-ion-pair Electron Transfer Mechanism for Photolysis of Diphenyliodonium Salt Sensitized by 9, 10-Dimeth- oxyanthracene-2-sulfonate Counteranion", Chem. Lett. pp.1869-1872, 1991
25) G.W.Wallaff, R.D.Aallen, W.D.Hinsberg, C.G.Willson : “A Chemically Amplified Photoresist for Visible Direct Imaging”, J. Imaging Sci. Technol. 36, p.468, 1992

26) S.Moon, K.Kamenosono, S.Kondo, A.Umehara, T.Yamaoka : "Three-Component Photopolymers Based on Thermal Cross-Linking and Acidolytic De-Cross-Linking of Vinyl Ether Groups. Effects of Binder Polymers on Photopolymer Characteristics”, Chem. Mater. Vol.6, No.10, pp.18541860, 1994

27) 今井玄児, 長谷川剛也, 岩島智明: “新規ポジ型レーザー直 描レジストシステム”, 塗料の研究, No.136, pp.58-67, 2001

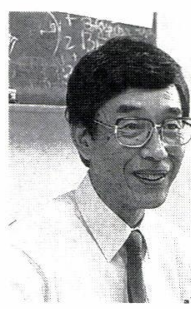

山岡 亞夫 (やまおかつぐお)

昭和14年生まれ。昭和37年, 千葉大学工学部写 真印刷工学科卒業。昭和46年, 理学博士（東京 大学)。昭和 47 年, ヒューストン大学化学科 (博士研究員)。昭和 49 年, 千葉大学助教授。昭 和57年，同工学部画像応用工学科 (現・情報画 像工学科) 教授。現在に至る。この間, IBM Almaden研究所（サンノゼ）にVisiting Scientistとして滞在。光機能性有機材料の研究 に従事。 